\title{
What Is Ethical Literary Criticism? \\ Some Reflections on the Lady Called Filosofia \\ in Dante Alighieri and the Following
}

\section{JÜRI TALVET}

\begin{abstract}
At the end of 2012, a new international association of literary scholarship was founded in China on the initiative of Chinese scholars, especially Professor Nie Zhenzhao of Wuhan Normal University, editor of the journal Forum for World Literature Studies. The main aim of the new International Association of Ethical Literary Criticism was to initiate a new trend of international literary scholarship that would form a certain counterweight to Western literary studies, which at least since the last quarter of the $20^{\text {th }}$ century have indeed oscillated between two extremes: on the one hand, linguistic-formalistic research (including narratology, cognitivistics, language philosophy applied to literature, etc.) and, on the other hand, sociological approaches (discourses on power relations, postcolonial scholarship, gender studies, etc.). As Nie Zhenzhao puts it in his pivotal speech (largely coinciding with Nie 2010), there was very little hope that big or small "peripheries", if they continued to follow the main fashionable trends proceeding from Western "centers", could ever contribute to universal literary scholarship or world literature studies with their own, original points of view, reflecting realities beyond "centric" Western literary currents and criticism and their faithful imitations in the "periphery".

The following is a reflexion about the possible origin of western ethical literary criticism (in the following abbreviated as ELC) in Dante Alighieri's philosophical treatise Convivio. My main claim is that the formation of a theory / philosophy of ethical literary theory ran in parallel with ethical practice in the first great European literary masterpieces of the budding new era - Dante's own monumental Commedia and the following creation of the early Italian Renaissance writers. On the other hand, I will try to show that ethics in literature in the Western tradition has been from its very beginnings till our days essentially conditioned by the presence in literary works of an aesthetic dimension, sensual beauty and arts.
\end{abstract}

Keywords: ethical literary criticism, Dante Alighieri, aesthetics, sensuality, arts, Rabelais, Joyce, Cervantes, García Márquez 
To begin, let me quote Nie Zenzhao:

It is no exaggeration to argue that Chinese literary criticism, since China's opening to the outside world, has been dominated by western critical theories. We should acknowledge the fruitful results brought by importing and applying western critical theories [...] but we feel that something is lost in this process. [...] More frankly, we had to admit that we have contributed very little to literary criticism except interpretation and use of ready-made critical approaches. We could not help pondering over the question whether there is any possibility for Chinese scholars to develop literary critical kits of their own and thus contribute to the world literary criticism. I think we should try by questioning the validity of the concepts we accepted and agreed. (Nie 2010: 2)

Though conceived in China, the new International Association of ELC ${ }^{1}$ is fully open to the contributions on these lines by western scholars, to conceptualize further the new current in literary criticism and demonstrate its applications to creativity in literature, especially from a comparative point of few. If we manage it, we may be pretty sure that the claim of Nie Zhenzhao in the subtitle of his conference paper, "Ethics as the Origin of Literature", does not appear exclusively applicable to Eastern literature, but has a lot to do with the core of major masterpieces of literature created in the world, East and West, in ancient times as well as in modernity.

In fact, the great Italian Dante Alighieri whose work at the closing stage of the European Middle Ages would be perfectly fitting to epitomize a cultural "explosion" in terms of Yuri Lotman ${ }^{2}$ - it was indeed a powerful breakthrough into a creative individuality unparalleled in the preceding medieval literature was not only the great author of a major poetic work but also one of the first bright Western thinkers at the climax of the Middle Ages and the budding new era. I would claim that he envisaged the first contours for a kind of theory or philosophy of both Ethical Literary Creation and Criticism. In his Convivio ${ }^{3}$ ('Banquet', written probably between 1304 and 1307) Dante provided a hierarchy of sciences, characterizing its highest levels as follows:

A l'ottava spera, cioè a la stellata, risponde la scienza naturale, che Fisica si chiama, e la prima scienza, che si chiama Metafisica; a la nona spera risponde la scienza morale; ed al cielo quieto risponde la scienza divina, che è Teologia appellata. (Dante Alighieri. Convivio II, XIII)

IAELC was founded in Yichang, China, during the international symposium "Ethical Literary Criticism: Theoretical Explorations and Criticism Practice" at China Three Gorges University, December 21-23, 2012.

2 See above all Lotman 1992; English translation: Lotman 2009.

3 It has also been published under the title Convito, thus in the edition of Dante's works consulted here, Dante Alighieri 1760. 
What Is Ethical Literary Criticism?

Natural science, which is called Physics, and the supreme science, called Metaphysics, correspond to the eighth Sphere, the Starry Heaven; Moral Science to the ninth sphere; and the Divine Science, Theology, to the unmoving heaven. (Trans. A. S. Kline)

Dante thus respected highly both physics and metaphysics (natural sciences and supra- or meta-natural sciences), aimed either at describing and measuring concrete bodily objects or developing a system of concepts aiming at describing as completely as possible the world beyond nature and the physical world. In both sciences, the human intellect (Intelletto), the secretion of the human mind, is a primary vehicle.

Yet, as is well known, even though recognizing Metaphysics as prima scienza (supreme science) Dante elevated moral science or Ethics to a still higher level, the ninth heaven, which is second only to Theology (scienza divina) and in Dante's poetic imagination inspired by Ptolemy, corresponded to the Primum Mobile, or the initial source of all movement of the Universe, putting into movement all other heavenly spheres.

Thus in Dante's conception, Physics and Metaphysics were separated from God and his science by the heavenly sphere of Ethics. (Only the oldest saints, the apostles like Peter, the founder of the institutionalized Church, dwelled in the presence of God in the Tenth Heaven.)

Dante's ninth sphere, the Primum Mobile, was not populated by mortals; its inhabitants were angels, incarnations of love and goodness, who acted as mediators between God and mortal souls; they were utterly free to fly in the Universe. Thus human intellect alone, omnipotent as it could seem, did not grant access to God's presence in Dante's imagination.

However, not only angels intermediated between God and humans as mortals. Dante's special attention was attracted by a woman, donna, whom he called Filosofia. She is the main character of Convivio. Dante returns to her once again in the final passage of the treatise which remained unfinished:

[...] suo mestiere discuopra là dove questa donna, cioè la filosofia, si troverà. Allora si troverà questa donna nobilissima quando si truova la sua camera, cioè l'anima in cui essa alberga. Ed essa filosofia non solamente alberga pur ne li sapienti, ma eziandio, come provato è di sopra in altro trattato, essa è dovunque alberga l'amore di quella. (Dante Alighieri, Convivio, IV, XXX)

[...] its purpose where this lady, namely Philosophy, is to be found. This most noble lady shall then be found when her dwelling-place is found, that is, the soul in which she dwells. And Philosophy does not dwell in the wise alone, but also, as has been above proved in another book, wherever the love of her dwells. (Trans. A. S. Kline) 
Dante's beloved Beatrice and the Virgin Mary (as Italian madonna means both madam and the Virgin Mary) greatly coincided with that lady, Filosofia. Even though Dante allegorized both real historical women, camouflaging them as Filosofia, he never failed to accentuate the gender aspect. (In such languages as Estonian, lacking the gender category and its respective articles, filosoofia, a foreign loan word, is deprived of any sensual-sexual colouring it has in Italian or other Romance languages; besides, in accordance with its historical practice, it rather tends to be associated with the gloomy and austere male-kind. On the contrary, angels in Estonian culture, at least outside the church walls and in popular imagination, have more than often been identified with females ...)

Furthermore, Dante accentuated the aspect of movement in the etymology of Filosofia. The source of the movement is "love". It is in full harmony with the nature of the ninth heavenly sphere, that of Ethics. To a greater extent than Physics and Metaphysics, the lady called Filosofia and Ethics deserves to be close to the Divine Creator, as their innate faculties are creativity and a strive to spirituality. Dante thus explained the origin of Filosofia:

Questo Pittagora, domandato se egli si riputava sapiente, negò a sé questo vocabulo e disse sé essere non sapiente, ma amatore di sapienza. E quinci nacque poi, ciascuno studioso in sapienza che fosse 'amatore di sapienza' chiamato, cioè 'filosofo'; ché tanto vale in greco 'philos' com'è a dire 'amore' in latino, e quindi dicemo noi: 'philos' quasi amore, e 'soph[os] quasi sapien[te]. Per che vedere si può che questi due vocabuli fanno questo nome di 'filosofo'che tanto vale a dire quanto 'amatore di sapienza': per che notare si puote che non d'arroganza, ma d'umilitade è vocabulo. (Dante Alighieri, Convivio III, XI)

When Pythagoras was asked whether he considered himself a wise man, he refused to accept the appellation for himself and said that he was not a wise man but a lover of wisdom. So it came to pass after this that everyone dedicated to wisdom was called a "lover of wisdom", that is, a "philosopher", for philos in Greek means the same as "love" in Latin, and so we say philos for lover and sophos for wisdom, from which we can perceive that these two words make up the name of "philosopher", meaning "lover of wisdom", which, we might note, is not a term of arrogance but of humility. (Trans. A. S. Kline)

Ché se a memoria si reduce ciò che detto è di sopra, filosofia è uno amoroso uso di sapienza, lo quale massimamente è in Dio, però che in lui è somma sapienza e sommo amore e sommo atto; che non può essere altrove, se non in quanto da esso procede. (Dante Alighieri, Convivio III, XII) 
For if we recall what has been said above, Philosophy is a loving use of the wisdom which exists in the greatest measure in God, since supreme wisdom, supreme love, and supreme actuality are found in him; for it could not exist elsewhere, except insofar as it proceeds from him. (Trans. A. S. Kline)

It is utterly important that in donna, either a real or an allegorical woman whose love can conduct man to God, love is never exhausted by sexual domination. It is a basic difference with simple earthy lovemaking between humans. That lady, Filosofia, a woman, preserves her "self", she does not let it be dominated by man, the traditional "first self" in history. It would not be impossible to claim that Dante and some of his great followers, like Petrarca, Montaigne, Cervantes, Calderón among others, envisaged the initial contours of feminist literary criticism, which is certainly not at all alien to ELC.

Dante made a great effort to assure us that he did not approve of senses and sensuality. To do so, he allegorized Beatrice, camouflaging her as Filosofia. Yet he would never deny that the real Beatrice who by the purity of her soul initiated him into divine feelings, did exist in reality.

As Dante in his Vita Nova suppressed senses, the poems there are predominantly intellectual, obsessed by philosophical reasoning. They seldom sound like lyrical poems. Yet scarcely half a century later, Francesco Petrarca, who too followed the general spirit and philosophy of dolce stil nuovo envisaged by Dante, wrote in one of his sonnets:

Come 'l candido pie' per l'erba fresca i dolci passi onestamente move, vertù che 'ntorno i fiori apra e rinove de le tenere piante sue par ch'èsca.

Amor, che solo i cor leggiadri invesca nè degna di provar sua forza altrove, da' begli occhi un piacer sì caldo piove, ch'i' non curo altro ben né bramo altr'ésca.

E co l'andar e col soave sguardo s'accordan le dolcissime parole. e l'atto mansueto, umile e tardo.

Di tai cuattro faville, e non già sole, nasce 'l gran foco, di ch'io vivo et ardo, che son fatto un augel notturno al sole.

(Petrarca 1986: 191) 
When her white foot through the fresh grass takes its sweet way, virtuously, from her tender steps there seems to issue a power that opens and renews the flowers.

Love who only hinders the gracious heart not deigning to try his strength in other ways, rains such keen pleasure from her lovely eyes I care for no other good, long for no other bait.

And those sweetest words of hers accord with her walk and her quiet gaze, as do her gentle, calm and humble acts. From those four sparks, but not merely those, is born the great fire in which I live and burn, like a bird of night dazzled by the sun.

(Trans. A. S. Kline)

Thus Petrarca did not at all deny that supreme good came to man through the senses (un piacer si caldo piove; di tai cuattro faville - the eyes of two lovers) and that it makes one feel like a night bird in the full sunshine, naked, without any defence mechanisms provided by reason. The earth (augel notturno - night bird) and heaven (il sole - the sun) become one in the act of love.

In Petrarca and Boccaccio, Dante's donna, Filosofia, was transformed into Madonna. Petrarch wrote his famous cycles of Italian poems dedicated to his beloved, "In vita di Madonna Laura" and "In morte di Madonna Laura". Boccaccio called his equally famous novel, written from a woman's point of view, Elegia di Madonna Fiammetta. Though fully retaining its spiritual content, Madonna at the same time - as compared with the still abstract donna in Dante - was turned into an individualized woman, an intimate and sensually perceived "my lady".

Even though the poetry of Petrarca and his numerous followers in the Renaissance has been somewhat simplistically labelled as "Platonic", it did mean a deep breakthrough. The lady Filosofia described by Dante in Convivio never abandoned her initial function to mediate human creation through the sphere of Ethics to God's presence. She has left her footprints in all great Western literature as we know it, until the present day. However, the symbolic veil of that lady was lifted and she started to appear ever more openly embodying love as well as love for wisdom in its essential sensuality, having her origin in the senses and sensitivity. 
From the above-said, one could say that Dante envisaged the contours for the nucleus of all human creation, including literary creation and, as the latter's most widely spread modern supplement, literary criticism - literature's explication and commentary. Following Dante's intuition, in all the sphere of creation wisdom should be inseparable from love. It is love for virtue, beauty and truth, both as a movement and the ultimate goal.

In all probability, the values contained in Ethics (ethos - custom, habit) can hardly be conceived beyond relating one's "self" to "other". Following Dante's argument, Ethics could be seen as an attempt to establish a loving relation with the "other". It is just an attempt, not anything definite, because only God, the supreme "Other" in whom eternal Light and Love are inseparable, is definite.

From the historical man's point of view - the prevailing viewpoint through all centuries of human memory - the "other", let alone God, means all living nature surrounding man, starting with man's closest "other", woman. Let us not forget an important aspect in this respect: as Dante conceived Filosofia (a lady, a woman) as the vehicle and nucleus of supreme human creativity, she is intrinsic in the creative subject itself. Thus Dante's Filosofia (love of wisdom, rather than possessed wisdom) seems to mean an eternal quest of a dialogue with the "other", in the broadest sense. It is quite contrary to such "knowing", cognition, of which the ultimate goal is domination, possession, and subjugation, if not annihilation of the "other" - a monologue of which the vehicle is knowledge deprived of love. Once again, quoting Dante's own words, " "lover of wisdom" [...] is not a term of arrogance but of humility".

Indeed, if we think of the greatest works of literature of the past and the present, in all of them a strong ethical nucleus is present. At the same time there is always room for debate. The margins of ethicality in significant literary works are frequently blurred, they are in movement, as life adapts new forms and is itself in a permanent state of openness, challenges and change. Ethics should never be understood as an established set of morals or moral rules in and for literature. It is just the opposite: it means reflecting on humans and their "others" in all their complexity, not simplifying anything, but not forgetting either the main vehicle of literary creation, Filosofia, or love of virtue, beauty and wisdom.

On the other hand, as literary works have seldom been created for the exclusive pleasure of the author or merely of a selected few, Dante and his immediate predecessors and followers paid great attention to the form, language and style of their work. Indeed, the new poetry aspiring to reach God through love transformed into philosophy and religion came to be called, in 
TALVET

Dante's own words, dolce stil nuovo. Dante introduced that notion in Canto 24 of "Purgatorio":

Oh frate, issa vegg'io, diss'egli, il nodo
che il Notaio, e Guittone, e me ritenne
di qua dal dolce stil nuovo ch'i' odo [...]

(Dante Alighieri 1930: 258)

"Oh brother, now I see," he said, "the knot which me, the Notary, and Guittone held short of the sweet new style that now I hear."

(Trans. H. W. Longfellow, Dante Alighieri 1877: 326)

I guess dolce could be interpreted here as the key word alluding to the power of the senses and feeling in the act of literary creation. They form the very core of a literary image capable of communicating with "others". Therefore, love of truth, beauty and virtue, embodied by Dante's Filosofia - or the condition of ethicality in literary creation - seems to have meant for Dante at the same time love for perfection in the way of expression and the form of literature.

All artistic creation that has broadly followed the message of Dante's Filosofia has been an existential quest within the narrow frames of our individual lives. It has remained always inconclusive. Yet the reward for creators is that, following their inner calling, they have conveyed the burning experienced in the flames of the Purgatory to those others, however few, who are not indifferent to the beauty of Dante's donna, Philosophy.

Dante did not mention explicitly the other donna who was close to his heart - Estetica. That lady had been especially active seducing poets and artists, many of whom appear in the Purgatory of Dante's Divina Commedia. There is hardly any doubt that the main sin of these artists and poets had been the openness of their senses to the sweetness, dolcezza, of that Donna, Estetica, or of some real woman camouflaged as Estetica. The original meaning of Aesthetics is "perception by senses". Dante's imaginary Estetica has her fullest epiphany at Purgatory's peak, often interpreted as the "terrestrial Paradise" in Dante. ${ }^{4}$ Before reaching Purgatory's peak (Canto XXVII), Virgil summarizes his role as Dante's guide:

See e. g. Henry W. Longfellow's lengthy commentaries to "Purgatorio" in Dante Alighieri 1877. 
Tratto t'ho qui con ingegnio e con arte;

lo tuo piacere omai prendi per duce.

(Dante Alighieri 1930: 272)

By intellect and art I have brought you;

take thine own pleasure for thy guide henceforth.

(Trans. H. W. Longfellow; Dante Alighieri 1877: 338)

The transition from the inferior stage of human perception (intellect and art combined) to the superior movement (intellect and religion combined, symbolized in Beatrice, or the lady Filosofia) is prepared in Divina commedia by another Roman poet, Statius, whom Dante and Virgil met first in Canto XXI of "Purgatorio". Statius joins both poets in their ascent, but while Virgil fades from beside Dante in Canto XXIX, Statius appears still accompanying Dante throughout the final four cantos of "Purgatorio". It is because Statius admitted Christianity or was at least Christian in his soul. (Longfellow' notes to "Purgatorio", Cantos XXI-XXII; Dante Alighieri 1877.)

In the same Canto XXVII there is a preliminary vision of Beatrice. She is not alone, but accompanied by another divine lady, Matelda, interpreted by Longfellow as the symbol of "active life", in contrast but also complementing the symbol of "contemplative life" in Beatrice. (Longfellow's notes to "Purgatorio", Canto XXVII; Dante Alighieri 1877). What is perhaps noteworthy in this context is that Matelda, much more than Beatrice, is presented by Dante in the sensual aspect of beauty. Whenever she appears, Dante does not fail to call her "bella donna". There is a sudden surprising shade of sensuality in the final scene of "Purgatorio", when Beatrice in the very end lines of Canto XXXIII asks Matelda to take Dante to the river Eunoè whose water would restore his memory of all good and noble things. Matelda of course does it but asks "in her womanly manner" ("ed a Stazio / donnescamente disse") also Statius to join Dante in taking part in the ritual of preparation for ascending to Paradise... What happened to Statius after it, Dante does not tell the reader. He just mentions modestly that he cannot continue the story because the pages envisaged for Purgatorio are full ("piene son tutte le carte / ordite a questa Cantica seconda"). Yet there seems to be also a more significant reason for not being able to continue: "The curb of art no father lets me go" ("Non mi lascia più ir lo fren dell'arte"). In other words, art alone by itself, even if complemented by intellect, cannot hope to ascend to the highest degrees of creation.

To conclude from the above said about ethics and ethicality in literary creation, I can hardly conceive of them as being beyond the senses, sensibility, openness to others and love (in whatever forms). In this complex, empathy, 
sympathy, passion as well as compassion have likewise their key roles. It nearly always means a reflection on our responses in a border-zone in which our passions, feelings, intellect and psyche become entangled in their most complicated interrelations. Ethics in literature very much resembles the lady whom Dante called Filosofia. It is not philosophy as a professional activity of the mind or the elaboration of a set of definitions and concepts taken for a final truth. It is rather a tentative movement of human thought which in artistic and literary creation can hardly escape being entangled and blurred in sensual images. If deprived of such a condition, a work of art or literature can scarcely surpass the borders of an author's "self", being for the most part unable to communicate with the "other(s)".

It would be utterly artificial to claim that ethicality in literature is a category somehow superior to aesthetics. I would rather claim that both belong to the very nucleus of literary creation. The closer they merge, the higher flights creativity can take in literature. Their separation from each other has never borne any significant fruits. Senses and sensibility are essential in the form of all artistic creation. They are the basis of metaphor - the basic means that differentiates artistic and literary creation from other types of mental activity, as well as embodying the climax of creative expression.

We cannot expect too clear-cut definitions of their work from writers. At its best, their theory or philosophy is hidden, implicit in their work itself. All great artistic creation works as an unpredictable "explosion". A pre-established rational-intellectual model or scheme would hardly fit a work that wishes to aspire to some transcendence beyond mere entertainment for the general reading public or some small sect of literary scholars.

It seems to be certain that in the highest achievements or "explosions" in the western canon of world literature Dante's lady Filosofia has always had her essential share. She has embodied the openness of the major works to the "other" on both the vertical and the horizontal axis - thus providing a strong presence of ethicality. A genuine creative "explosion" in literature has hardly become a reality without the closest (and always highly original) symbiosis of ethicality with arts, or aesthetics. It could even be said that Filosofia, in the meaning that can be deciphered from Dante's work, represents simultaneously ethics and aesthetics. Nearly always their convergence in a major literary work has meant a revolt against preceding patterns and norms established in both ethics and aesthetics. Let me provide below some brief examples, both from the "centre" and the "periphery" of western literary history so far.

The constitution of any "centre" is naturally debatable and its borders have never been fixed or stable. Yet it seems to be undeniable that historically literary creation in the West has formed "centres" above all on the linguistic 
ground. Works created in French, English, and German have formed their main axis from the Renaissance to the present day. Italy's domination of the Renaissance and the Spanish sporadic "intervention" from the end of the $16^{\text {th }}$ century through to the $17^{\text {th }}$ century, or the Baroque, could be rather seen as deviations from the rule. As European Romanticism ushered in first stage of "cultural globalization", Russia and the Scandinavian countries, as well as the "Europoid" America - North and South -, started to enlarge the Western "centre". However, it is also true that until today the centric axis, though definitely extended since the $19^{\text {th }}$ century on the basis of English into North-America, has kept other big European areas and the "Europoid" SouthAmerica at a distance, as a kind of "semi-peripheries".

After the great pioneering literary creation of Dante, Petrarca and Boccaccio, the first truly European masterpiece in the Western canon was probably François Rabelais's Gargantua and Pantagruel. That extravagant book, published in French between 1532 and 1552, with a problematic end part appearing in 1562, gave ground four centuries later to a genuine "explosion" in the field of literary philosophy, as the Russian Mikhail Bakhtin published in 1965 his pivotally influential comparative-semiotic analysis of Rabelais masterpiece (Bakhtin 1965). Rabelais's revolt against the fruits of dogmatic reason in all spheres of society, very much in unison with the philosophical satire of Desiderius Erasmus in his Praise of the Folly and Thomas More's Utopia (the latter being surely even a much earlier creative "explosion" than Rabelais's) would probably never have achieved its fame had the author written his work in a more traditional language and style. Rabelais's main philosophic idea - to be easily grasped even without Bakhtin's help - was to show, just as Erasmus had shown before him, the inexhaustible greatness of nature and vital (biological-telluric) totality. It shows as relative and ridiculous all human aspirations of power, attempts to dominate the world and establish reason-based rules forever. However, to do it, Rabelais did not limit himself to a traditional language and style, but clearly tried to make the form of the work itself amplify and magnify his philosophy. The book looks as if Rabelais had wanted to demonstrate the greatness of vital totality with its unrestrained liberties by introducing a language and a style totally open to all possibilities, in a permanent unpredictable movement and capricious change, not obeying any rational rules established and invented by scholars, theologians and philosophers.

James Joyce, the greatest revolutionary innovator of the novel genre in the $20^{\text {th }}$ century, did almost the same. The great protagonist of his Ulysses (1922) is language. As Rabelais, Joyce seemed to have tried to embrace all possible levels of language and style, including coarse everyday talk, abundant colloquialisms, 
academic and cultural discourse, elliptical and disfigured syntax, deformed orthography, hybrid words, interlingual puns, neologisms and archaisms, polyglotism, and so on. Exactly as Rabelais before him, Joyce constructed some of the chapters of his novel in the form of catalogues and lists of names, while in other chapters he introduced devices of drama, relying on dialogue.

Scholars specializing in Joyce and Rabelais have studied in great detail the parallels between both writers, for the most part trying to detect and trace direct influences. Paradoxically, Joyce himself denied having ever read Rabelais... (Korg 2002).

Would it really matter if there were direct influences reaching from Rabelais to Joyce? I suppose more important by far is the new inimitable and original synthesis of ethics and aesthetics in every great work of literature. For a truly creative mind it is enough to have only a vague idea of some philosophic or artistic novelty, in unison with his/ her own perceptual-creative search, either concerning form or content. Joyce might not have read Gargantua and Pantagruel in the original French, but maybe for instance he still had peeped into Thomas Urquhart's English translation of Rabelais' chef-d'oeuvre. In the latter, the translator has adopted formal liberties absent in most other editions, in the sense that quotations marks have been suppressed and the text looks very much like quite a number of passages in Joyce and the following $20^{\text {th }}$-century innovative prose fiction writers. Thus, a short typical example from Urquhart's translation runs as follows:

Well, well, said the harbinger. But, said Gargantua, guess how many stitches there are in my mother's smock. Sixteen, quoth the harbinger. You do not speak Gospel, said Gargantua, for there is sent more, and sent behind, and you did reckon them ill, considering the two under holes. When, said the harbinger? Even then, said Gargantua, when they made a shovel of your nose, to take up a quarter of dirt [...]. Cocksbod, said the steward, we have met with a prater. (I, 12; Rabelais 1952: 16)

However, there could have been totally different sources for such a style, defying rationally conceived formal norms of orthography. Punctuation marks were most radically abandoned in the early vanguard poetry since at least the eve of WWI, with the introduction of free associations of images, fragmentation, and intentional mixture of the conscious and the sub-conscious (Apollinaire, expressionist and futurist poets), immediately preceding Joyce.

In the ethical content magnified by artistic-linguistic novelty Joyce also resembled in part Rabelais, as the overwhelming point of view of both Gargantua and Pantagruel and Ulysses hardly surpasses masculine / male imagery. Still, 
while Rabelais's book, written in a satirical-critical vein, inevitably had to provide a vision from "outside" the depicted reality, never touching the characters' interior life, Joyce, a $20^{\text {th }}$-century author, not only could rely on the vast experience of preceding realism in western literature, but could absorb inspiration from some of the great masterpieces of the past in which realism escapes simple definitions, as their philosophy / ethics cannot be separated from their artistic-aesthetic novelty. I mean first of all Miguel de Cervantes' Don Quixote, created in the historical border-zone of the Renaissance and the Baroque.

A reader finds it much easier to follow the story in Don Quixote than in the masterpieces of Rabelais and Joyce. However, the apparent realistic simplicity of Cervantes's work is highly deceptive. In the same way as Cervantes following Dante Alighieri's lady Filosofia made ethics and aesthetics thoroughly converge in a novel unity, he managed to create an illusion of a story that was at any moment both reality and myth. To achieve such magic, he introduced in his novel several intermediating narrators. He went as far as to deny his authorship and to claim that the story had existed long before he took up writing down its Spanish translation dictated by a Moorish-Spanish boy...

The fictional illusion created by Cervantes the magician attains its peak in the transition from Don Quixote's Part I to Part II, when it appears that Don Quixote and his faithful companion Sancho Panza can themselves read what has been written about their adventures. As a result, the readers cannot any longer keep their distance from the created fictional-mythic reality but are dragged into the myth and made to share the existential quest of the fictional characters as if it were their own life with its limited time span, especially as the novel's adventure is interrupted and abruptly concluded by Don Quixote's recovery from his madness and his subsequent death.

Cervantes' magic-realistic vision of reality which for the first time in the history of the novel embraced the tragic-existential dimension of human life, is the ethical-aesthetic background for a number of key works in the Western canon, like Franz Kafka's and Gabriel García Márquez’s novels and stories at the beginning and end of the $20^{\text {th }}$ century, respectively. Similarly with Cervantes - and very differently from Rabelais or Joyce - Kafka was no innovator of form. However, his grasp was deeper, entering the creative zone in which ethics and aesthetics become practically inseparable. He alienated his characters from the reader by making them follow a different logic from the daily one guiding our mainly rationally conceived behaviour. It was the logic or rather the absence of logic of our nightly dreams.

A similar kind of magic transcending of merely formal-fictional play is at work in García Márquez's novel A Hundred Years of Solitude. The Colombian writer is probably the only writer of fiction after Cervantes who has managed 
TALVET

to make myth and reality merge in such a way that the total image penetrates into the readers' senses, to become an image symbolizing the painful path of humanity's historical existence. As in the romances of chivalry before Cervantes, love is the main source of magic.

However, "magic realism" would never properly work without realism. Historical realism in literature is basically a social phenomenon. Without the presence of the social and historical "other", including women beyond their traditional role, the fictional magic, however brilliant, would become limited in its impact. In Don Quixote, the female protagonist, Dulcinea, is at the same time a simple village girl and the lady Filosofia who invisibly as Dulcinea physically never appears in the novel - guides the action of the work to a philosophical conclusion of humankind's unity as an ideal based on love, self-sacrifice, and soul's nobleness. The final image of A Hundred Years of Solitude - as it appears that the story told in the novel has already been related as a myth in the secret manuscripts of the gipsy sage Melquíades - makes myth and historical reality magically merge in a powerful symbol of humankind's doom and ruin, the result of male-kind's power ambitions and selfishness. Yet the novel at the same time presents a poly-dimensional vision of the historical woman and a call for love reaching from the "telluric" prostitute Pilar Ternera to "Platonic" Remedios la Bella. Very much like Dante's Filosofia, the women of García Márquez's novel unite beauty and ethics, providing for humankind despite its vices some hope of redemption.

To adapt the conclusions of the reflexion above to the field of comparative literary research, I am convinced that literature's potential as a spiritual guide of any nation and the world community as a whole should be revealed beyond formal and sociological schemes. Instead, we should concentrate our attention on literature's historical core as envisaged by Dante Alighieri and other greatest writers-philosophers. Literary research should overcome its present condition in the West and worldwide, where it has been overwhelmingly and contradicting its nature forced into the role of a mere appendix of formalistlogical sciences and sociology. The task is to research and teach comparatively the existing active canon of world literature and at the same time keep it in a state of permanent openness. A desirable convergence of comparative literary research and ELC should crucially enhance the inclusion in the canon of world literature of the "other" - important works of literature created in languages beyond the traditional Western "centric" area. It is high time to redeem them 
What Is Ethical Literary Criticism?

from their "fatal condition" of having been created exclusively for their "own" ethnic-national community.

\author{
Jüri Talvet \\ juri.talvet@ut.ee \\ Tartu Ülikool \\ Kultuuriteaduste ja kunstide instituut \\ Ülikooli 16 \\ 51014 Tartu \\ EESTI
}

\title{
References
}

Bakhtin, M. 1965. Tvorčestvo Fransua Rable i narodnaya Kul'tura srednevekov'ya $i$ Renessansa. Moskva: Khudožestvennaja literatura. (Бахтин, М. 1965. Творчество Франсуа Рабле и народная культура средневековья и Ренессанса. Москва: Художественная митература.)

Dante Alighieri.Convivio. - http://www.filosofico.net/conviiviodante.htm(16.01.2014) English translation by A.S. Kline - http://www.poetryintranslation.com/ PITBR/Italian/ConvivioII.htm\#_Toc189547314 (16.01.2014)

Dante Alighieri. 1760. Convito. - Opere. V. Prose, e rime liriche. Venezia: Appreso Antonio Zatta, 65-279.

Dante Alighieri. 1877. Divine Comedy. Trans. Henry Wadsworth Longfellow. London: Georg Routledge \& Sons.

Dante Alighieri. 1930. La divina commedia. Introduction and commentaries by Eugenio Camerini. Milano: Casa Editrice Sonzogno.

Korg, J. 2002. Polyglotism in Rabelais and Finnegans Wake. - Journal of Modern Literature, Vol. 26, No 1, 58-65 (http://muse.jhu.edu/journals/jml/summary/ v026/26.1korg.html; 10.01.2014).

Longfellow, H. W. 1877. Notes to Purgatorio. - Dante Alighieri, Divina Commedia. London: George Routledge \& Sons, Canto XXVIII-XXIX.

Lotman, Y. M. 1992. Kul'tura i vzryv. Moskva: Progress. (Аотман Ю. М. 1992. Культура и взрыв. Москва: Прогресс.)

Lotman, Y. M. 2009. Culture and Explosion. Trans. Wilma Clark. Berlin, New York: Mouton de Gruyter.

Nie Zhenzhao. 2010. Towards an Ethical Literary Criticism: Its Fundaments and Terms. - Foreign Literary Studies, Vol. 32, Issue 1, 12-22.

Petrarca, F. 1986. Il canzoniere. Milano: Gruppo Editoriale Fabri, Bompiani, Sonzogno. English translation by A. S. Kline - http://www.poetryintranslation.com/ PITBR/Italian/PetrarchCanzoniere123-183.htm (16.01.2014)

Rabelais, F. 1952. Gargantua and Pantagruel. Trans. Sir Thomas Urquhart and Peter Motteux. Chicago London-Toronto: Encyclopedia Britannica. 